Review

\title{
Food and Wine Pairing in Burgundy: The Case of Grands Crus
}

\author{
Benoît Lecat ${ }^{1, *}$ and Claude Chapuis ${ }^{2}$ \\ 1 Wine and Viticulture Department, California Polytechnic State University, 1 Grand Ave, Building 11, \\ San Luis Obispo, CA 93407-0861, USA \\ 2 School of Wine \& Spirits Business, Burgundy School of Business, 28, Rue Sambin, 21000 Dijon, France; \\ Claude.Chapuis@bsb-education.com \\ * Correspondence: blecat@calpoly.edu; Tel.: +1-805-756-2415
}

Academic Editors: Edgar Chambers IV and Robert J. Harrington

Received: 5 November 2016; Accepted: 3 February 2017; Published: 9 February 2017

\begin{abstract}
Burgundy is known both for its wines and its food products but they developed independently from each other. This paper examines the long march towards maximal wine quality which started before the beginning of the Christian era. In the Middle-Ages, the Cistercian monks brought up the notion of terroir which eventually led to the AOC system (Protected Designation of origin) in 1935. Burgundy is also blessed with good farming land. Furthermore, the production of quality vegetables, fruits and meat contributed to the birth of its regional cuisine. However, it was not until the beginning of the 20th century that Burgundy's original gastronomy gained recognition. It should be noted that this process was rather laborious. The advent of tourism introduced French and foreign visitors to the region's lifestyle. With UNESCO's listing of the vineyards of Côte de Beaune and Côte de Nuits as part of the world's heritage and the development of wine tourism, Burgundy intends, at long last, to capitalize on its assets. An inventory of wine and food pairing complements this paper. Finally, a brief description of the term terroir will introduce the key contribution of this paper: how and why Burgundy Grand Cru wines pair so well with foods. For each of the 33 Grands Crus, a review of the best wine-food matches will be discussed on the basis of the specificities of each Grand Cru wine.
\end{abstract}

Keywords: Burgundy; Grands Crus; food pairing; Chambertin; Montrachet; Romanée-Conti; Musigny; Corton-Charlemagne; terroir; Burgundy climats

\section{Introduction}

Nowadays, Burgundy wines and food are no longer mainly consumed locally or in France but they are celebrated all over the world. In 2015, the Bourgogne Wine Board (BIVB) pointed out that $50 \%$ of the wines were exported. As for the home market, $28 \%$ were consumed in restaurants (especially by tourists visiting Beaune, a natural stopover because of its location at the crossroads of three major Southbound Highways) and 22\% bought them in supermarkets, hard-discount stores, retail or wine shops.

What is more, according to INSEE (French National Statistics Institute), nearly half a million people stopped in Burgundy in 2011, according to the figures of recorded stays in hotels. Therefore, part of the $28 \%$ Burgundy wines consumed in restaurants are paired with local food when foreigners visit Burgundy or France. Grands crus attract tourists who want to better understand the terroirs of the region. The focus of this article is to help them identify adequate food pairings with their Grands Crus when they visit Burgundy and/or consume their favorite wines at home.

This article will review food and Grands Crus pairing. It will first describe the historical context and the way a "food-and-wine" culture emerged in Burgundy. Then, a section on Burgundy wines 
will describe the 33 Grands Crus. It will be followed by an overview of the local food production: the main courses that have made Burgundy famous will be listed. Indeed, given the incredible variety of Burgundy wines and the equally incredible variety of food resources, pairing wine and food is both easy and challenging. For many years, cooks served local food with local wine but today, in a global context, the question of pairing Burgundy wine with more exotic food is raised. Finally, the principles of pairing Burgundy wines with food in general and local food will be examined. The discussion will focus on the historical evolution.

\section{Objectives and Methodology}

This paper is mainly based on a historical approach followed by an advanced literature review on the villages where Grands Crus are located, the grands Crus themselves, the inventory of local food and finally, on the best pairings. It is a review paper.

To introduce Burgundy wines, it is important to understand the historical context and the evolution of wine quality over time:

- In the Middle-Ages, the Cistercian monks brought up the notion of terroir which eventually led to the AOC system (Protected Designation of origin) in 1935.

- Burgundy also possesses good farming land and quality productions of vegetables, fruits and meat that contributed to the birth of its regional cuisine.

- The beginning of the 20th century marked Burgundy's awareness of its assets even if the development of tourism took time. In a recent past (July 4, 2015) UNESCO added the vineyards of Côte de Beaune and Côte de Nuits to the list of places belonging to the world's heritage. Such a recognition is expected to give a new impetus to "wine-and-food tourism."

Although Burgundy is known both for its wines and its food products, they are rarely analyzed jointly. The purpose of this paper is to bring together the literature of these two assets of the region through first a separate review of village and Grand Cru wines on the one hand, and an inventory of local food on the other hand.

The key contribution of this paper is to list all the pairings of Burgundy Grands Crus with food. For each of the 33 Grands Crus, a review of the best-pairings is proposed from the angle of the sensorial characteristics of each Grand Cru wine. The originality of the paper is actually about how and why the unique Burgundy Grands Crus wines pair so well with all kinds of foods and particularly the great cuisine of Burgundy.

\section{Historical Context of the Emergence of a Food and Wine Culture in Burgundy}

The rising interest in food and wine started in the 18th Century and was accelerated by the development of the car industry, the wine roads with the creation of the Michelin Guidebook and the organization of events such as "la foire gastronomique (gastronomic fair) of Dijon" and the chapters of the "Brotherhood of the Chevaliers du Tastevin".

\subsection{Some Famous Visitors' Impressions}

Although Burgundy boasts one of the richest architectural and gastronomic heritages in France and produces some of the world's best wines, for a long time, the fame of its vineyards was not enough to attract tourists with some minor exceptions. Most testimonials show the visitors' lack of interest in vines.

From March 4 to March 10, 1787, Thomas Jefferson [1], then US ambassador in France, visited the province because he meant to introduce vines to the newly independent country. In his notebooks, Jefferson outlined a map on which he mentioned the names of La Baraque (Marsannay), Chambertin, Vougeau, Veaune, Romanie, Nuys, Beaune, Pommard, Voulenaye, Meursault, Montrachet. He described the relief and the nature of the soils, because he wanted his project to be as precise as possible. 
On 2 August, 1789, English agronomist Arthur Young [2], traveled from Dijon to Beaune by cabriolet. He stopped at Clos de Vougeot and noticed that no trees had been planted in the Cistercians' estate whereas peach trees, plum trees, cherry trees dotted the other vineyards of the province ... He was not impressed by the 650-year old history of the Clos and thought that the vineyards of Champagne were more beautiful.

In April 1806, Napoleon sent Madame de Staël [3], who opposed him into exile in Northern Burgundy. Provincial life bore her to death. The hills covered with vines that she saw from her window stirred no emotion in her. She complained that the view she had was limited to a "horizon of posts."

Historian Jules Michelet [3] was another unimpressed traveler who shared Madame de Staël's negative judgment. He found it sad with its "death-grey posts" and its hills with an often barren top.

In his Memories of a Tourist, Stendhal [4] used the word "tourist" for the first time in the title of a book. A genuine wine lover who appreciated the good life, he was more interested in people than in landscapes. His opinion of the wine-producing hills was negative, to say the least: "If it were not for its wonderful wines, I would find nothing uglier in the world than this famous Côte d'Or. Côte d'Or is just a small, very dry, ugly little mountain; but one makes out the vineyards with their small posts, and all the time one finds an immortal name: Chambertin, Clos de Vougeot, Romanée, Saint Georges, Nuits. With the help of so much glory, one finally gets used to Côte d'Or."

However, American novelist Henry James [5] (1884) who saw the hills of Côte d'Or shortly after the grape harvest mentioned "the charm of the landscape" and even found the slopes "picturesque."

In his book On Reading, (1906) [6] Marcel Proust spoke of the pleasure he took when he walked in the cobbled streets of Beaune but he did not mention vineyards. As a matter of fact, it is hard to imagine the author of Remembrances of Things Past venturing along vineyard trails in hiking boots.

Thus, for a long time, the beauty of vines was not acknowledged. Burgundy was the region tourists passed through on their way to the Riviera. At best, places such as Auxerre, Dijon, Beaune, Chalon sur Saône and Mâcon were stopovers. In 1912, as recorded by Laferté [7], the tourist information office of Burgundy advised visitors not to visit the vineyards: "You may go from Gevrey to Nuits via the National Road and you'd be going past the most famous crus of France ... But for tourists in love with natural beauty, this route is uninteresting." It must be noted, however, that before the phylloxera crisis (1878-1895), vines were planted in a disorderly, unkempt, and anarchic way. It was only after the phylloxera crisis, when vines were re-planted, aligned along straight rows that visitors changed their appreciation, adopting poet Charles Baudelaire's view that beauty was born from order.

\subsection{Emergence of Events Attracting Tourists}

The wine auction of the Hospices de Beaune, which was initiated in 1859 [8] remained a major event. On the day following the sale, the Paulée of Meursault takes place in the château of the village. "Paulée" is the end of vintage meal traditionally offered by estate owners to thank grape pickers for their work. This event gathers together Meursault estate owners and 600 guests who taste the wines offered. The three events: the Hospices Wine auction banquet at Clos-de-Vougeot on Saturday, the wine auction and popular celebrations in Beaune on Sunday and the Paulée of Meursault on Monday are referred to as the Trois Glorieuses (three glorious days).

Like grapes taking their time to ripen, things change slowly in Burgundy. The Trois Glorieuses are still celebrated in November in Clos-de-Vougeot, Beaune and Meursault. However, the wine auction of the Hospices of Beaune has been organized by Christie's since 2005 in a desire to expand the international renown of the most famous "charity wine auction in the world." The auction is usually chaired by a show business star and the highlight of the event is the sale of "the chairperson's barrel" which reaches a sky high price. The entire amount paid for this special barrel is given to a charity organization chosen by the chairperson. This episode is hyped by the media and the generous bidder is offered maximum visibility.

In 1934, in the thick of the Great Depression, the Brotherhood of the Chevaliers du Tastevin ("Knights of the Wine Tasting Cup") was founded by two wine merchants from Nuits Saint Georges. 
There was no market for good quality Burgundy wines, stocks were very high, whatever wines were sold left cellars at rock bottom prices. Louis Chapuis's father [9] remembered that in the thirties, when he sold the content of a 228-liter barrel, he did not get enough money to buy an empty new oak barrel. The idea expressed by the brotherhood was to invite wine lovers from all over the world to Nuits Saint Georges and make them discover the crus of the region. Their chapters were soon very much sought after: artists, writers, scientists, movie stars, politicians and even royals swarmed to Clos de Vougeot after World War 2. They, in turn, became ardent propagandists of Burgundy wine. This successful attempt was imitated and today, many villages throughout Burgundy have their own brotherhood.

The first Saint Vincent Tournante, the celebration of the wine growers' patron saint, on the week-end following Saint Vincent's day (January 22), took place in Chambolle-Musigny in 1938. From then on, this major event has been held in a different village every year. It requires months, if not years of preparation. No wonder it attracts thousands of visitors.

\subsection{The Car Industry, Grands Crus Road and the Michelin Guide}

In 1905, Michelin, the tire manufacturer, published its first Guidebook. At that time, car tourism was budding. The people who could afford to buy a car and take holidays belonged to the wealthy strata of the population. Car owners needed the addresses of garages in case of breakdowns which never failed to occur. They also wanted good places where they could stay overnight and good restaurants where they could enjoy quality cuisine. In the guidebook, car owners could find the addresses of garages, hotels and restaurants with comments.

The first French wine road was inaugurated in Burgundy in 1934 but what made Burgundy famous was in fact the now mythical Route Nationale 6 lined with renowned restaurants in Joigny, Avallon, Saulieu, Arnay-le-Duc, Chagny, Tournus, Mâcon ... These celebrated places had been coaching inns before being turned into gastronomic restaurants when the car industry emerged. However, slowly but surely, the Route des Grands Crus which crosses the vineyards of the Côte de Nuits and the Côte de Beaune became more popular. Writer Jean-François Bazin [10] often refers to it as "the Champs-Elysées of Burgundy". Since the opening of that first wine road, many others have been opened in France's wine regions. In Burgundy alone, there are several of them.

Cultural tourism also developed in Burgundy, a province boasting a very rich heritage. Among these "cultural" roads, let us mention the roads of history (the Romanesque road, the Cistercian routes in Yonne, the roads of the Dukes of Burgundy, the road of the chateaux of Southern Burgundy, the Lamartine road ... ) and the roads of Nature's traditions (the cider road in Pays d'Othe, the wall paintings road in Puisaye, the Tonnerrois washhouse road, the road of Bresse, the Loire barge road, the green road (for cyclists and hikers) between Beaune and Santenay ... ). In 1971, Highway A6 linking Paris to the Riviera was opened. It bypasses some of these gastronomic places, but attempts have recently been made to revive RN 6. Nevertheless, many tourists will go out of their way to eat in stared restaurants ... La Côte Saint Jacques in Joigny, L'Espérance in Saint Père sous Vézelay, Côte d'Or (Bernard Loiseau) in Saulieu, Chez Camille in Arnay le Duc, Maison Lameloise in Chagny are still favorite stopping places for gourmets).

Every year, more wine professionals welcome visitors to their cellars along the route des grands crus. Today, their number is close to 200. In many villages, in the Côte d'Or at least, visitors may find their bearings thanks to signs or viewpoint diagrams displaying blowups of cartographer Sylvain Pitiot's very precise maps [11,12]. However, it must be pointed out that, in conformity with Burgundy's values: "Good wines needn't advertising!" advertising remains low key.

\subsection{La Foire Gastronomique de Dijon and the Emergence of a Food Culture}

In the mind of many people, Burgundy means good living, good wine and good food. Vineyards thrive on the poor clay, limestone and marl soils of the "Côte." The rich soils of the region enable farmers to produce quality products in Charolais (beef) in the Yonne plains (fruit and especially 
cherries,) Nivernais (dairy products,) the Morvan range (pork meat,) the Bresse plains (poultry,) the Saône Valley (wheat, onions, mustard.)

We will not go so far as to write that gastronomy appeared only recently in Burgundy but it was highlighted only after World War 1 . Its products were excellent but its cuisine remained a well-kept secret. An elaborated, refined cooking based on wine sauces developed in the 19th century. As Burgundy is a crossroads subjected to many different influences, it managed to take advantage of all possible opportunities. Thus, people from the Bresse adopted the Inca corn imported by their Spanish masters in the 16th century to feed their hens, Morvan people raised pigs in their big forests, wine growers collected snails and picked dandelions and lamb's lettuce on their way back from work... Wily gourmets borrowed recipes from other provinces, notably Auvergne, and gave them Burgundian citizenship by adding wine sauces.

More than in any other region, wine cannot be separated from food. Gastronomy does not simply consist in preparing dishes and planning the order in which they should be served but also in choosing the wines which will accompany them, wine enhancing food and vice versa. The match between wine and food is an art and it is said that wines should not be chosen to accompany food but food should be chosen to accompany wines.

At the beginning of the 20th century, the tourists stopping in Burgundy were unimpressed by luxurious hotels. They were usually hard-working entrepreneurs who wanted to fully enjoy the few vacation days they took. They were in search of simplicity and appreciated unpretentious inns and traditional cooking ... "We want to eat steaks, not Louis XIV armchairs," wrote a critic quoted by Gilles Laferté [7]. Only upstarts, "nouveaux riches", snobs, appreciated cuisine based on caviar, truffles, foie gras, which did not require efforts, just money.

The evolution of Burgundy's gastronomy was under way: a new approach to cooking consisting in preparing ordinary food in a creative way developed.

After World War 1, many people realized that the world was changing fast, too fast. Some historians such as Eugen Weber [13] claim that the end of World War 1 was the real beginning of the 20th century and they consider it was also the end of "peasants." Philosopher Michel Serres [14] says the vanishing of the peasant world was the main event of the 20th century because it put an end to a period which had started with the Neolithic Age. Feeling that the world they had lived in was perhaps on its way out, many artists and intellectuals developed a regionalist vision. Gastronomy, considered as a fundamental element of the good life, was put forward. Gaston-Gérard [15], a barrister and professor of law and advertising at Burgundy School of Business, understood the importance of tourism in Burgundy's economy. His ambition was "to revive the cooking and gastronomic traditions of the province of Burgundy, illustrated by its famous wines and the equally famous cuisine of its dukes."-quoted by Laferté [7]. He considered that tourism was an economic asset, a tool of economic growth which could benefit the country. In 1919, this ambitious young lawyer was elected mayor of Dijon, his hometown which he intended to turn into a major tourist destination and a gastronomic center.

By promoting tourism and gastronomy, Gaston-Gérard aimed to help farmers (the suppliers of quality natural products,) hotels, restaurants, and local shops. There was never heavy industry in Dijon, a city of art and history but the food industry presented an interesting potential. In 1911, it accounted for $28.7 \%$ and Dijon was one of France's leaders in the sector of food. Over 1000 employees were on the payroll of the Richard brothers (Pernot biscuits factory) between the two World Wars. Likewise, Armand Bizouard founded what was to become the Amora mustard company in 1919. The food sector was also represented by such flagships as the ginger bread brands Mulot and Petitjean, Philbée or Michelin, cassis companies such as Lhéritier-Guyot, Lejay-Lagoutte, Briotet and Boudier, the Lanvin chocolate company ... All of them found markets in France and abroad.

Lucien Richard (Pernot biscuits) together with Mayor Gaston-Gérard created the gastronomic fair in order "to revive the old rank of capital once held by Dijon" [15]. Their project was not readily accepted by the food industrialists of Dijon. A ridiculously low budget was allocated to the planning of the fair which was first held in November 1921. Nevertheless, it met with a rousing success. In 1925, 
600,000 visitors showed up at the two-week event which still takes place every year at the beginning of November.

Michelin contributed to the recognition of regional cooking. A reaction against the changing times characterized by increasing urbanization and standardization of life developed. Burgundy was to benefit from that new state of mind. In restaurants, cooks made a point of serving dishes referring to the place of origin of the ingredients used, thus giving them a regional identity. Diners ate Burgundy snails, frog legs from Saint-Germain-du-Bois, eels from Seurre, crayfish from Ozerain, asparaguses from Ruffey-les-Echirey or Vergigny, ham from the Morvan, chicken from Bresse, coq au Chambertin, and cheese from Epoisses or Cîteaux. "Saddle of hare à la Piron" reminded Burgundians of the 18th century fun-loving author of comedies. The names of the Dukes of Burgundy, which were given to some dishes, added a touch of aristocratic flavor to the food, as was the case of "pâté truffé Charles le Téméraire." From then on, Dijon became known as a gastronomic capital and a tourist center.

In 1929, Marie-Louise Fisher [16] a newly-wed American woman, arrived in Dijon where she was to spend three years. In Burgundy's capital, she developed her interest in gastronomy. She reported her discoveries in her book "Long ago in France, the years in Dijon", reissued in 1991. The passages that she wrote about Dijon and Burgundy give a good idea of the atmosphere of the region between the two World Wars and the high regard in which cooking was held.

When she and her husband had enough money, they patronized the Trois Faisans, Mr Racouchot's famous restaurant: In her book, she goes on describing the kind of meals served there.

When the young couple finally left Dijon, she commented: “We were fleeing. We were refugees from the far-famed Burgundian cuisine. We were sneaking away from a round of dinner parties that, we both calmly felt sure, would kill us before another week was over." Eventually, she became one of the world's most celebrated writers on food and came to be known as the "Colette of the Napa Valley".

Winegrowers found their salvation in the AOC system they designed to impose strict rules on the production of wine. The decree of 1935 eventually put an end to their difficulties. According to this system, each appellation is specified by its area of production, the authorized cultivars, the pruning method used, the training system of the vine, the yield authorized and the minimum and maximum alcohol content. Of course, it is complex because of the large number of Burgundy appellations but it is very logical and it has never been seriously questioned.

This system was soon extended to other products, notably cheese. The characteristics of cheeses (type of milk, location of meadows, ingredients, fat content ... ) were determined according to strict specifications. Thus, Cîteaux, Chaource, Epoisses, and more recently, Mâconnais and Charolais cheeses obtained their "identity card", a certification of compliance with strict specifications guaranteeing their quality. Such regulations apply to Burgundy's beef, lamb, pork, poultry, rabbit, wheat, cooked snails ... As for mustard, Dijon mustard, which contributed to the fame of the town, is a brand, not an appellation. It can be made anywhere in the world as long as the Dijon recipe is applied. The Fallot Company in Beaune produces its mustard with seeds coming exclusively from the region. Burgundy's producers have applied for an IGP (protected geographical indication) and, in all likelihood, one day, a "moutarde de Bourgogne" appellation will be created.

After the Second World War, the flamboyant canon Kir was elected mayor of Dijon. He renewed with the tradition of offering "blanc cass" (two-thirds aligoté wine one-third cassis) to his guests. In so doing, he intended to help the producers of aligoté wine who were not as prosperous as their counterparts producing chardonnay or pinot. Though he did not invent the "blanc cass" tradition, his name was associated with that drink. Aligote wine, produced in big quantities, was so acidic that it was almost undrinkable. It was even nicknamed "wine of three" because it was said that it took three people to drink it, one to hold the glass and two to maintain the drinker on his chair. Blending this tart product with sweet black currant made sense. Kir, being a popular character in Dijon and bearing an easy-to-pronounce name, was delighted to give his name to "blanc cass". Serving kir to guests is still a must today. 
The notion of terroir has become prominent of late. This untranslatable word which refers to soil, aspect, weather conditions, traditions, uses and production methods, has also become a good marketing argument. Terroir highlights the strong typicity of local produce. Burgundy ranks very high in France with its terroir products.

"Red label", a national distinction, (law of 2006) applying to higher quality products distinguishes the best of Burgundy's beef, poultry, rabbit and pork meat. However, French farmers have not yet cottoned on to organic or biodynamic farming and informed consumers seem to be more wary of GMOs (Genetically Modified Organisms) in food than of non-organic farm products.

Those are the many assets of Burgundy. However, we may wonder whether it has fully become aware of them. So far, wine tourism in Côte d'Or has been still relatively undeveloped in spite of some key successful private initiatives $[17,18]$.

- 'Cassissium', located in Nuits-Saint-Georges, is an interactive museum which introduces visitors to the world of cassis ('blackcurrant').

- 'Imaginarium' helps visitors discover the sparkling wine-making process through an interactive museum, a tasting room, sensory workshops and a boutique.

- In Beaune, 'big' négociants have recently opened their production facilities (Louis Jadot) or their historical wine cellars (Joseph Drouhin). Domaine Drouhin has decided to opt for a high-class tour of their cellars and the tasting of six wines, for wine buffs. Prices range from $€ 38$ to $€ 250$ (special dinner).

- Food and wine pairing is available at key-wine players', in Puligny-Montrachet with the 'Table d'Olivier Leflaive' and in Aloxe-Corton with the 'Table du Domaine Sénard'.

- The 'Château de Chassagne', located in Chassagne-Montrachet is a renovated 12th century castle: it offers a complete wine tourism product with five exclusive chambres d'hôtes (guest rooms,) visits of the 12th century cellars, organization of weddings and conferences, wine tasting at the boutique and free entrance to an art gallery.

- The Caveau de Puligny, the Caveau de Chassagne, the Caveau d'Aloxe-Corton and other similar points of sale in different villages offer a great choice of wines made by nearly all local producers.

- A major Busisness-to-Business event takes place every other year in Beaune, 'Les Grands Jours de Bourgogne', where importers, journalists, wine writers and various influencers are invited for a week in spring to taste the wines of the different sub-regions of Burgundy.

\section{Burgundy Wines}

In this section, some statistics on Burgundy wines will be mentioned to highlight the importance of Grands crus (33 appellations out of 100) accounting for only 1.4\% of the production. Then, each village will be briefly described to illustrate the diversity of profiles (the villages where Grands Crus are located are followed by $a^{*}$ in Section 4.2). Some other villages are also presented because even if they do not have Grands Crus, their premiers Crus are so special they could easily compete with some Grands Crus. Such is the case of Beaune, Meursault, Pommard, Volnay or Nuits-Saint-Georges. It is important to point out that both Nuits-St-Georges and Pommard have applied to have some parcels upgraded to Grands Crus.

\subsection{Statistics on Burgundy Wines and Definition of the Concept of Climat}

Burgundy wines are made with only one cultivar which is never blended: pinot noir for red wines (34\%) and chardonnay for white wines (48\%). There is also some Gamay (for the reds: $10 \%$ ) and some Aligoté (for the whites: $6 \%$ ) and 2\% of other varietals such as Pinot Beurot (Pinot Gris). In 2015, BIVB published its statistics: Burgundy produced 1.4 million hl (or 187 million bottles) with $61 \%$ white wines, $29 \%$ red wines and rosé, 10\% sparkling Crémant de Bourgogne. About $1.4 \%$ of the total production consists of Grands Crus, around $47 \%$ are village and premiers crus appellations and $52 \%$ are regional appellations. 
For more information on the key figures for the Bourgogne winegrowing region, see $[19,20]$.

Regarding the appellations, there is a total of 100 appellations (PDO, protected designation of origin). The appellation system is based on a 4-tier hierarchical ranking (from top to bottom):

- Level 1: Grands Crus: 33 accounting for $1.4 \%$ of the production;

- Level 2: Premiers crus (first growth), accounting for 10\% of the total production;

- Level 3: Village (communal) appellations, accounting for $36.6 \%$ of the total production;

- Level 4: Regional appellations, accounting for $52 \%$ of the production.

In terms of appellations, there are 33 Grands Crus PDO, 44 village and premier cru (first growth) PDO and finally, 23 regional PDOs.

Referring to Lucand [21], we can point out that the production increase was quite significant before the phylloxera crisis (1878-1895), but also that the weather conditions strongly influenced the harvested quantity. Even if old data are not always highly reliable (compared to current ones), the analysis of the production over time shows that the quantity of wine available on the market is smaller nowadays and it has consequences in terms of price-setting especially since wine consumption is no longer just local or national but becoming more international.

Table 1 illustrates the quantity produced in 2010 (no updated data are available). Some key figures to have in mind refer to production: around 151.4 million bottles and the structure of production is as follows:

- About 3785 estates (among which 1121 bottle their production and sell more than 10,000 bottles a year), which accounted for $26 \%$ of the sales in 2010 ;

- 300 wine merchant companies (maisons de négoce) which represented $58 \%$ of the sales in 2010;

- 17 co-operatives: $16 \%$ of the sales in 2010 .

In 2015, 50\% of the production was exported and the global turnover of Burgundy wines was around 1.45 billion euros, which represents $3 \%$ of the global wine trade in terms of value and $18 \%$ of revenue for still French AOC wines on the export market (whereas Burgundy only represents 3\% of the total French production).

Table 1. Production per department in Burgundy in hectoliters.

\begin{tabular}{ccccc}
\hline Department & Estates & Ha & White (hl) & Red (hl) \\
\hline Yonne & 655 & 6600 & 350,000 & 30,000 \\
Côte d'Or & 1260 & 9700 & 200,000 & 279,000 \\
Saône et Loire & 1870 & 13,200 & 475,000 & 180,000 \\
Total & 3785 & 29,500 & $1,025,000$ & 489,000 \\
\hline
\end{tabular}

Source: Adapted from Pitiot and Servant (2010), [12].

\section{The Climats}

Climat, a term which is almost exclusively used in Burgundy, designates a place name and has nothing to do with the weather. It refers to place. It has an identity, a memory. It is usually precisely marked out, but seldom surrounded by walls, it is intangible. This term designates a place and the wine which comes from it. Some objective traits characterize it: pedology, soil microbiology, microclimate ... It also reflects man's influence: trellising, work methods, winemaking methods ... It is both a simple and a complex notion because it expresses a value system which is typical of the region. In fact, Burgundy has chosen to lean against "climats." Unlike Bordeaux which leans on property and brand, Champagne which leans on brands, Alsace which leans on cultivars, Burgundy has chosen to lean on landed entity. Climat names have existed since the Middle Ages but paradoxically studies of their etymology show that their denomination was inspired by factors which had nothing to do with vines. Let us give a few examples [11]: 
- Identity: Chambertin, (originally: Bertin's field) Clos du Roy (the king's estate,) Romanée-Conti (Prince Conti's Romanée plot) etc.

- Soil: Perrières (stones,) Cras (limestone,) Caillerets (pebbles) Grèves (sand) Argilières (clay) etc.

- Shape of the soil: Combettes (coombs) etc.

- Type of vegetation: Genevrières (juniper,) Chassagne (oak trees), etc.

The word "climat" gradually, replaced that of "place name" as more vineyards were planted. A quality hierarchy ensued all the more as vines were tended by stable institutions such as monasteries.

Jean-François Bazin [22] writes that until the 18th century, wines, regardless of their origin were sold as "Burgundy wine" without any further precision. As they were mostly sold by Parisian or foreign merchants, simplicity prevailed. Very few growths were identified by consumers. Things changed in the 18th century. For instance, Thomas Jefferson, a great connoisseur, mentioned Mr Bachey's Meursault Goutte d'Or 1784, which shows his awareness of climat. At that time, only the most famous place names were referred to as climats. In 1855, Doctor Lavalle [23] established a distinction between place names ranking them according to quality criteria. Climats were definitely recognized when the AOC system was implemented. Small estate owners who sell bottles direct from the estate are really attached to them because they are an excellent promotion argument. The media also favor this situation. The Premier Cru law, which was voted in 1942 considerably increased the fame of climats, a term which so far had only applied to grands crus. In Côte d'Or alone, there are 635 Premier Cru "climats!" The AOC system marked the victory of climats over brands.

In July 2015, the "climats" of Burgundy were recognized as part of UNESCO's World heritage. In so doing, the United Nations Agency acknowledged the faith, determination and stamina of the people, serfs, lay monks, workers, clerics, aristocrats and bourgeois who, over a period of 2000 years established a terroir-based viticulture in Burgundy. Thus, the mosaic of Burgundy's vineyards is unique in the world because the identity of the different plots has always been privileged and protected. A total of 1247 climats in the Côte de Beaune and the Côte de Nuits may have been distinguished by UNESCO but there are many more between Chablis and Mâcon.

\subsection{The Importance of Villages Where Grands Crus Are Located and Their Authentic Taste}

Most of the pairings are suggested by the literature, especially Fromont [24,25], Poulain [26], Meffre and Covin [27], Carpentier [28], Downie [29], Morin [30], de Grand-Maison [31], Guicheteau [32], Bourguignon [33], Delpal J-L, [34], Simon [35], Harrington [36], Food and Wine the Westin [37], Goldstein, E., Goldstein, J., Pool, J. [38]. The most significant villages listed below illustrate the diversity of Burgundy's wines. Though two vineyards are separated by just a path, they may produce two very different kinds of wine (e.g., in Aloxe-Corton Les Perrières produces a firm, full-bodied wine which is tannic in its youth whereas Les Languettes which is next to it produces smooth, elegant, subtle red wines. In fact, the soil of the latter is suited to chardonnay and the white wine made in Les Languettes bears the Corton Charlemagne appellation). However, on the whole, the style of each village is fairly homogeneous. It will invite a specific food pairing. All the villages with a star have a Grand Cru. The brief description of the wine characteristics of each village will give an idea of their taste. The pairing of Grands Crus with food will be highlighted because they are more subtle and elegant and benefit from a unique micro-climate within the village. In fact, it is more a meso-climate than a micro-climate (the local climate of a whole vineyard.)

The name of the villages is important because some of them are less famous than their Grands Crus, at least for non-connoisseurs. It is maybe due to the fact that at the end of 19th Century when it was difficult to sell wines, wine villages decided to add the most prestigious parcels of the village (often located in what became later on Grand $\mathrm{Cru}$, in 1935) to their name. For example, the village of Gevrey added Chambertin to become Gevrey-Chambertin. Many other villages such as Morey-Saint-Denis (referring to Clos-Saint-Denis), Chambolle-Musigny, Vosne-Romanée, Flagey-Echézeaux, Aloxe-Corton, Chassagne-Montrachet, Puligny-Montrachet, etc., did the same. Some villages that do not have any 
Grands Crus such as Nuits-Saint-Georges or Auxey-Duresses also jumped on the bandwagon. In the following sections, the villages with a star * will have Grands Crus parcels on their territory.

\subsubsection{Chablis *}

These wines are dry, lively and even sinewy when young. They are subtle, fine, and elegant. They have hazel nut, honey and acacia aromas. A Chablis should be drunk after at least 3 years, a Premier Cru after 5 years and a Grand Cru after 10 years. Their aromas are long-lasting. Chablis wines accompany oysters, shellfish, veal stew, snails, small offal sausages ... and Chinese cuisine.

The total production of Chablis, Chablis Premier Cru, Chablis Grand Cru and Petit Chablis is $286,374 \mathrm{hl}$ or 38.183 million bottles (see www.chablis-wines.com) among which one percent is Chablis Grand Cru (3.8 million).

\subsubsection{Gevrey-Chambertin *}

Generous wines with a hint of red berries and black berries which express themselves with time. Then, they acquire a bouquet of field and forest, orchard, undergrowth and liquorish. They are powerful without being heavy. They accompany cock with wine (coq au vin), legs of mutton, game, venison, jugged hare and strong cheese. The production for the village appellation (without the premiers crus) is around 2 million bottles a year.

\subsubsection{Morey-Saint-Denis *}

The red wines of Morey-Saint-Denis are keepers. These strong-bodied wines have aromas of berries (blackberries, black currants or wild cherries) which become jammy with time. They accompany red meat such as Châteaubriand (double fillet steak), quail with mushrooms, guinea-fowl, cock in wine, strong cheeses. The production for the red village appellation is around 262,000 bottles a year.

\subsubsection{Chambolle-Musigny *}

The most elegant and finest wines of the Côte de Nuits, "wines of silk and lace". They have a fruity bouquet. They accompany grilled red meat, feather game (quail, woodcock and partridge,) mushrooms (chanterelles,) duck, tenderloin as well as fruity cheeses which are not too strong (cîteaux, reblochon). Marinated game and too strong sauces must be avoided. The production for the village appellation is around 520,000 bottles a year.

\subsubsection{Vougeot *}

These wines characterize themselves by their aromas of vanilla and spices. They have a good length. They accompany savory red meat, autumn dishes such as turkey and chestnuts, wild boar, veal stew ... The red production for the village appellation is around 60,000 bottles a year of red wines and 20,000 bottles of white wines.

\subsubsection{Vosne-Romanée *}

The wines of Vosne-Romanée are very fine and complex with fruity, floral, undergrowth and spicy aromas but always very elegant. According to 18th century historian Courtépée [39], "there are no minor wines in this village." These wines accompany ham pie, deer, wild boar, duck, and cock in wine, grilled beef cutlet, roast young partridge, woodcock, pheasant, feathered game, hare, rabbit and fruity cheese. The production for the village appellation is around 0.5 million bottles a year.

\subsubsection{Nuits-Saint-Georges}

Elegant and strong-bodied, these tannic wines are keepers. When they age, they develop a bouquet of humus, smoke, tobacco and undergrowth. They accompany marinated red meat, hare, deer, guinea-fowl, duck, boeuf bourguignon, oeufs en meurette (poached eggs in a red wine and onion 
sauce) and strong cheeses. The red production for the village appellation is around 835,000 bottles a year.

\subsubsection{Aloxe-Corton/Pernand-Vergelesses/Ladoix-Serrigny *}

The red production for the Aloxe-Corton village appellation is around 0.55 million bottles a year and 3000 bottles for the white wines. Some pairing ideas with red Aloxe-Corton wines: roast chicken, steak with peppercorn (without cream), rabbit with mustard, mutton. In Pernand-Vergelesses Village Appellation, around 260,000 bottles a year for the red and 174,000 for the white wines are produced. In terms of pairing for the red wines: grilled red meat, poultry, lamb, duck or turkey with chestnuts. For the white wines: quiche lorraine, grilled zander, Comte cheese. The production of Ladoix is around 350,000 bottles of red wines and 65,000 bottles of white wines. In terms of pairing for the red wines: lamb chops, lamb fillet, ostrich, fruity cheese, roasted meat with a light sauce. Chicken, foie gras, raclette cheese, smoked salmon are to be eaten with white Ladoix.

\subsubsection{Beaune}

The red wines of Beaune are elegant, distinguished and well-structured with aromas of red berries (raspberries and cassis.) They accompany red meat, game (leg of venison), pigeon, beef, roasted boar and lamb. The white wines of Beaune are a little reminiscent of Meursault wines. They accompany small pike dumplings, fish, and white meat. The red production for the village appellation is around 540,000 bottles a year and the white production is around 72,000 bottles.

\subsubsection{Pommard}

Well-structured, tannic wines with complex aromas of prune, liquorish and even animal. They accompany roasted red meat, ribs of beef, marinated meat, jugged hare, and strong cheeses such as Munster. The production for the village appellation is around 1.1 million bottles a year.

\subsubsection{Volnay}

Pleasant, silky, delicate red wines with aromas of violet and strawberry. They have a good length and age well. They accompany quail, Navarin lamb, small strips of duck breast, haunch of venison. The production for the village appellation is around 0.5 million bottles a year.

\subsubsection{Meursault}

This village mainly produces white wines which are rich and have a good structure with a beautiful green-gold hue. They have a bouquet of linden flower and almond which evolves towards quince, hot brioche, and ripe fruit. They accompany fine fish in a sauce and white meat. The white production for the village appellation is around 1.9 million bottles a year and the red production represents 72,500 bottles.

\subsubsection{Chassagne-Montrachet/Puligny-Montrachet *}

Alexandre Dumas considered that Montrachet was the greatest white wine in the world, worthy of accompanying the best dishes: lobster, foie gras, turbot... The village and Premier Cru appellations of Puligny are characterized by their subtle flavors of caramel, white flowers, honey, mint, exotic fruits, fern, almond paste but also citrus, dried fruits (especially for the Premiers Crus). They both have a good structure and distinction. They accompany fine fish (sole, turbot,) scallops, calf's sweetbread stew and curried chicken.

Chassagne characterizes itself by its hawthorn, acacia and honeysuckle aromas with hints of verbena. Minerality is also present with flintstone notes. As this wine ages, it acquires aromas of honey. Chassagne wines are the ideal partners of white meat in a sauce, salmon and also Asian food (curry, wok.) Red Chassagne reveals aromas of dry apricot, herb tea and honey. It accompanies beef, venison, roasted pork and Epoisses cheese. The white production for the Puligny-Montrachet 
village appellation is around 0.8 million bottles a year and the reds represents 7700 bottles whereas the production for the Chassagne-Montrachet village appellation is around 434,000 bottles a year for the white wines and 570,000 bottles for the red wines.

Some other villages are not presented in this review because they do not have Grands Crus or cannot claim to have any cru that could compete with their famous neighbors. It is the case for Santenay, Saint-Romain, Saint-Aubin, Auxey-Duresses, Montagny, Blagny, etc., or in the Côte Châlonnaise, Mercurey, Rully, etc., or Pouilly-Fuissé in the Macon area.

\subsection{Grands Crus and Parcels}

As mentioned above, the specific location of a plot or the climat concept explains why Burgundy Grands Crus, though very close to each other are very different. Harrington [36] refers to the micro-climate concept or the climate specific to an individual plot within a vineyard by opposition to macroclimate (climate of an overall region) and meso-climate (the local climate of a whole vineyard). In this section, a list of the 33 Grands crus of Burgundy (out of 100 appellations) is established. In Table 2, the region of origin of each Grand Cru is mentioned (Chablis, Northern Burgundy in the Yonne Department, Côte de Nuits or Côtes de Beaune in the Côte d'Or Department; there is no Grand Cru in the Côte Châlonnaise and Mâconnais). Then, for each Grand Cru, the village where they are located is mentioned and the color and surface in ha (one ha being the equivalent of 2.47 acres). It is also important to point out that there is only one Grand Cru Appellation in Chablis although there are seven areas/plots spread over 99.79 ha: Les Clos (25.87 ha), Blanchot (12.68 ha), Grenouilles (9.38 ha), Valmur (10.55 ha), Vaudésir (15.43 ha including La Moutonne Monopole), Preuses (10.81 ha), and Bougros (15.07 ha).

Table 2. List the Grands Crus (presented from North to South).

\begin{tabular}{|c|c|c|c|c|c|}
\hline$\#$ & Grand Cru & Area & Village & Color & Surface in ha \\
\hline 1 & Chablis Grand Cru & Chablis & Chablis & White & 99.79 ha \\
\hline 2 & Mazis-Chambertin & Côte de Nuits & Gevrey-Chambertin & Red & 9 ha 10 a 34 ca \\
\hline 3 & Ruchottes-Chambertin & Côte de Nuits & Gevrey-Chambertin & Red & 3 ha 30 a $37 \mathrm{ca}$ \\
\hline 5 & Chapelle-Chambertin & Côte de Nuits & Gevrey-Chambertin & Red & 5 ha 48 a $53 \mathrm{ca}$ \\
\hline 6 & Griotte-Chambertin & Côte de Nuits & Gevrey-Chambertin & Red & 2 ha 69 a $18 \mathrm{ca}$ \\
\hline 7 & Chambertin & Côte de Nuits & Gevrey-Chambertin & Red & 12 ha 90 a $31 \mathrm{ca}$ \\
\hline 10 & Mazoyères-Chambertin & Côte de Nuits & Gevrey-Chambertin & Red & 18 ha 58 a $68 \mathrm{ca}$ \\
\hline 11 & Clos de la Roche & Côte de Nuits & Morey-Saint-Denis & Red & 16 ha 90 a $27 \mathrm{ca}$ \\
\hline 12 & Clos Saint-Denis & Côte de Nuits & Morey-Saint-Denis & Red & 6 ha 62 a $60 \mathrm{ca}$ \\
\hline 13 & Clos des Lambrays & Côte de Nuits & Morey-Saint-Denis & Red & 8 ha 84 a 02 ca \\
\hline 14 & Clos de Tart & Côte de Nuits & Morey-Saint-Denis & Red & 7 ha 53 a $23 \mathrm{ca}$ \\
\hline 15 & Bonnes-Mares & Côte de Nuits & $\begin{array}{l}\text { Morey-Saint-Denis and } \\
\text { Chambolle-Musigny }\end{array}$ & Red & 15 ha 05 a 72 ca \\
\hline 19 & Grands Échezeaux & Côte de Nuits & Flagey-Echézeaux & Red & 9 ha 14 a 45 ca \\
\hline 20 & Richebourg & Côte de Nuits & Vosne-Romanée & Red & 8 ha 03 a $45 \mathrm{ca}$ \\
\hline 21 & Romanée-Saint-Vivant & Côte de Nuits & Vosne-Romanée & Red & 9 ha 43 a $74 \mathrm{ca}$ \\
\hline 22 & Romanée-Conti & Côte de Nuits & Vosne-Romanée & Red & 1 ha 80 a $50 \mathrm{ca}$ \\
\hline 23 & La Romanée & Côte de Nuits & Vosne-Romanée & Red & 0 ha 84 a $52 \mathrm{ca}$ \\
\hline 24 & La Grande Rue & Côte de Nuits & Vosne-Romanée & Red & 1 ha 65 a $25 \mathrm{ca}$ \\
\hline 25 & La Tâche & Côte de Nuits & Vosne-Romanée & Red & 6 ha 06 a $20 \mathrm{ca}$ \\
\hline 26 & Corton & Côte de Beaune & $\begin{array}{l}\text { Pernand-Vergelesses and } \\
\text { Ladoix and Aloxe-Corton }\end{array}$ & White and Red & 160 ha 19 a 39 ca \\
\hline 27 & Corton-Charlemagne & Côte de Beaune & Ladoix-Serrigny & White & $\begin{array}{c}71 \text { ha } 90 \text { a } 84 \text { ca } \\
\text { (incl. Le Charlemagne) }\end{array}$ \\
\hline 28 & Le Charlemagne & Côte de Beaune & $\begin{array}{l}\text { Aloxe-Corton and } \\
\text { Pernand-Vergelesses }\end{array}$ & White & 62 ha 94 a $03 \mathrm{ca}$ \\
\hline
\end{tabular}

Source: Adapted from Landrieu-Lussigny M.-H., Pitiot S., (2014), [11]. 


\subsection{Vintages}

Among all the red Burgundy vintages he tasted during his career as Wine Director for the Auction House Christie's, Michael Broadbent [40,41] considered that those which stood out (and remained drinkable and enjoyable) were:

- In the 19th Century: 1811, 1846, 1865, 1875;

- In the 20th Century, before 2nd World War: 1906, 1911, 1915, 1919, 1929, 1937;

- $\quad$ After the 2nd World War: 1945, 1949, 1959, 1962, 1969, 1978, 1985, 1988, 1990, 1999;

- Wine critics generally consider that 2002, 2005, 2009, 2010, 2012 stand out. Furthermore, the 2015 and 2016 vintages, produced in small quantities appear to be very promising even if the wines are too young to formulate a final judgement.

Ageing wines used to be a French tradition because during their youth, they were too tannic and not that elegant. This was especially true for Grand Cru appellations. With such techniques as destemming, shorter vatting periods, shorter ageing in barrels, maturation in underground cellars in maintaining a steady temperature all year round: (around $12 \mathrm{C}^{\circ}$ or $53 \mathrm{~F}^{\circ}$ ), the wines were becoming more expressive and elegant over time. Thus, with time, Burgundies acquire aromas and flavors of game, spices, earth, dried fruits and truffles. This is why black truffles, which have a wild, musky, earthy depth, beautifully accompany Romanée-Conti, Musigny, the great Côtes de Nuits wines or Corton. Likewise, older pinots, whose fruit character is more restrained, favor more savory, earthy dishes. They go well with feathered game: grouse, partridge, pheasant and dishes with truffles.

In 2000, the famous three-star-chef Alain Senderens [42] showed how unique each old wine bottle is and therefore deserved a food creation.

In 1938, the Ministry of Foreign Affairs hosted a reception in honor of King George VI and Queen Elizabeth. In his analysis of the menu, Bonin [43] listed the wines which were served: Demoiselle Montrachet 1921, Château Lafite 1924, Clos Vougeot 1923, Champagne Veuve-Clicquot 1928, rare old port 1875, Grande Fine Champagne (Cognac) 1848. In his book, Poulain [26] (p. 221) shows the example of a typical Burgundian lunch menu offered in 1948 by the "Brotherhood of the Chevaliers du Tastevin" for the General Assembly of the French Journalists' Union: old vintages: Pouilly-Fuissé 1943, Beaune Premier Cru 1943, Nuits Clos de Thorey 1937, Clos de Vougeot 1938 and then old Marc (brandy) were served.

\subsection{Ratings and Price}

The Revue des Vins de France was founded by Raymond Baudoin in 1927. It encouraged the owners of famous vineyards and clos to make their own wine instead of selling them in bulk to wine merchants, because the latter blended them with other wines. The American wine writer Frank Schoonmaker wholeheartedly agreed with this approach. In 1936, after Prohibition was lifted, he started Frank Schoonmaker Selections in New York City. Together with Baudoin, he played a seminal role in creating a market for wines bottled by growers rather than by merchants. From then on, an increasing number of authors started writing on Burgundy wines. As from the 1970s, wine writers were very eager to discover unknown producers. The media became very influential and humble growers, men of the soil, suddenly rose to the status of stars. Among these writers and journalists, we may mention, Broadbent [40,41], Coates [44], Johnson [45], Meadows [46], Morris [47], Parker [48], Remington and Taylor [49], Remington [50] and Hanson [51]. Some of them also write columns in newspapers. Such is the case of Jancis Robinson in the Financial Times. These authors may therefore be considered as influencers since consumers tend to follow their advice when purchasing wine. In many US shops, merchants posted the ratings given by critic Robert Parker and customers purchased the best-rated bottles. If a producer obtained a grade lower than 90 out of a maximum of 100, his wines risked not to remain on the shelves. Unfortunately, some producers also unwisely followed critics' recommendations. Thus, the word "Parkerization" was coined: it meant making wine appreciated by Robert Parker. We could go as far as to say that today, there is an "over-coverage" of wine news, which has of course 
an impact on prices, especially given the scarcity phenomenon (for the Grands Crus). There is no denying that the most famous critics have become a major factor in setting prices. However, the scarcity factor accounts even more for the high prices reached by some wines. In her Wine Course, Jancis Robinson gave the example of Henri Jayer who produced only 600 bottles of Cros Parentoux (not even a Grand Cru wine) every year. No wonder the bottles reached a stratospheric price. Although Corton fully qualifies as a Grand $\mathrm{Cru}$, its sales price never matches that of Chambertin or Musigny because its total surface amounts to 160 hectares ( 400 acres) against 13 hectares ( 32.5 acres) for Chambertin and 9.75 hectares (24 acres) for Musigny.

\section{Inventory of Local Food and Terroir}

The mere mention of the name Burgundy nowadays conjures up the thought of top-quality wines and gastronomy, but this reputation has been built over time. As was mentioned earlier, the real take-off of Burgundy's gastronomy coincided with the development of the automobile industry.

It must be noted that the phylloxera crisis had led some winegrowers to turn to other agricultural productions such as black currants. Liquor makers started producing cassis and their companies still exist today, some at the industrial level (Lhéritier-Guyot, Lejay-Lagoutte, Boudier, Védrenne,) others at the cottage industry level (Briotet, Jouannet).

Based on Poulain [26], Meffre and Covin [27], Carpentier [28], Downie [29], Morin [30], Table 3 shows an inventory of the major food products made in Burgundy.

Table 3. Inventory of traditional food made in Burgundy.

\begin{tabular}{|c|c|}
\hline $\begin{array}{l}\text { (1) Bakery and pastry } \\
\text { - Pain d'épices de Dijon, (Ginger Bread) } \\
\text { - Gimblette, (iced ginger bread cake) } \\
\text { - Nonnette, (small, iced gingerbread cake) } \\
\text { - Cion et Fra (tartes au fromage blanc), } \\
\text { - Nougatine de Nevers, (nougatine of Nevers) } \\
\text { - Bread } \\
\text { - Gougères (puffed cheese choux) } \\
\text { (2) Cooking with wine } \\
\text { - Chabrot (wine poured in soup) } \\
\text { - Trempée (wine with bread and sugar) } \\
\text { - Meurettes or Eufs en meurette (poached eggs in a red } \\
\text { wine and onion sauce) } \\
\text { (3) Meat } \\
\text { - Chicken: poulet de Bresse; coq au vin; Fricassée de } \\
\text { volaille de Bresse à la crème (poultry fricassee) and } \\
\text { poulet Gaston Gérard; the following products have the } \\
\text { GPI (Protected Geographical Indication) Bourgogne: } \\
\text { Poulet, chapon, pintade, oie fermière. } \\
\text { - Rable de lièvre (hare saddle) and Civet de lapin (rabbit) } \\
\text { - Beef: Charolais (with red label); Bøuf bourguignon; } \\
\text { pot-au-feu (Beef broth) or daube (meat braised in wine); } \\
\text { Entrecôte Bareuzai (winegrower's sirloin steak) } \\
\text { - Mutton/Merino } \\
\text { - Pork: Boudin (Blood sausage); Andouille de Clamecy } \\
\text { - French offal sausage); Saucisson (sausage); Jambon } \\
\text { persillé (Ham cooked with parsley) Jambon du } \\
\text { (4) Desserts } \\
\text { - Raisiné Bourguigno budru. }\end{array}$ & $\begin{array}{l}\text { (5) Fish } \\
\text { - Sea fish and fresh water fish (pike, carp, perch, fresh water } \\
\text { crayfish, eel) } \\
\text { - Brochet à la Dijonnaise (Dijon pike) } \\
\text { - Truite à la Bourguignonne (Burgundy trout) } \\
\text { - Pochouse (fresh water fish stew in a white wine sauce) } \\
\text { (6) Cheese } \\
\text { - Epoisses (with AOC), } \\
\text { - Citteaux, } \\
\text { - Soumaintrain, } \\
\text { - Chaource, } \\
\text { - Brillat-Savarin } \\
\text { - Délice de Bourgogne, } \\
\text { - Aisy cendré, } \\
\text { - Charolais } \\
\text { (7) Local specialties } \\
\text { - Mustard seeds } \\
\text { - Escargots (snails) } \\
\text { - Frog legs } \\
\text { - Oil (canola, rape seed) } \\
\text { (8) Other specialities from Burgundy } \\
\text { - Vegetables: beans, peas, cabbage, potatoes, Asparaguses } \\
\text { from Ruffey, cornichon d'Appoigny (gurkins), oignon } \\
\text { - P'Auxonne, (onions,) Burgundy truffle. } \\
\text { - Salads: dandelion, mâche (lamb's lettuce,) cabbage, wild } \\
\text { - Anis seed candy } \\
\text { - Fruit: apples, pears, cherries, strawberries, raspberries, } \\
\text { plums, apricots, Cassis de Bourgogne, cerise marmotte } \\
\text { (wild cherry), pruneau de Vitteaux (prune) } \\
\text { Beverages: Cassis, Kir, Ratafia, AOC Marc et fine de } \\
\text { Bourgogne (Grappa- and brandy-style). }\end{array}$ \\
\hline
\end{tabular}

Source: Adapted from Poulain [26], Meffre and Covin [27], Carpentier [28], Downie [29], Morin [30]. 


\section{Towards a Definition of Terroir}

Although the French word terroir is not translated into other languages, it is not a marketing ploy to sell French wines. It is what American writer Matt Kramer [52] (1993) defines as "a sense of somewhereness". It corresponds to a reality including the combination of soil type, micro-climate, aspect, and drainage. However, it is also much more than that. Man played a big part in the construction of terroir. Of course, most of the time, this term is associated with Burgundy whose viticulture history is a continuum of quality starting even before the beginning of Christianity in the area. Contrary to the other French wine regions, where vines were planted on the banks of major rivers (Rhône, Garonne, Loire, Saône, Yonne, Marne, Moselle...) vines were planted on the hills of Burgundy with the ancestors of Pinot. After the year 1000, thanks to the efforts of monks who tended their clos, the idea of terroir began to make its way although the word did not exist at that time. The best plots were identified by monks, especially Cistercians as of the 12th century. Burgundy's wine map has not changed much since the end of the Middle-Ages (end of the 15th Century.)

The 18th century saw the establishment of 'climats', known under the same name since the Middle Ages. Their precise location, soil, subsoil, aspect, microclimate and history constitute the characteristics of the unique personality of terroirs. The implementation of the AOC system confirmed the monks' observations. Nevertheless, the term terroir did not have a positive meaning until the 1960s. A "taste of terroir" even referred to a bad wine taste.

Things changed at the end of the 20th century. The word then referred to "typicity" (describing the way a wine reflects its origin.) Thus, it demonstrates the signature characteristics of its production area, its mode of production and its cultivar. The quest for typicity in an appellation wine was highlighted by its taste related to terroir, a guarantor of its originality. It is not by chance that the Burgundians raised the flag of terroir. In this region, estates are traditionally small and wine-growers often make their own wine. In the Côte de Nuits and the Côte de Beaune alone, the average area of a climat is 5 hectares (12.5 acres.)

From a theoretical point of view, Ballantyne [53] has argued that the guiding promise of terroir is socially constructed. He gave the example of Central Otago, in New Zealand, where vintners grow pinot noir in small plots, very much in the Burgundy way. Spielmann and Charters [54] developed a conceptual model of terroir dimensions related to authenticity: legal recognition of terroir products; physical nature of terroir products; and subjective perceptions of terroir products. Terroir is used to develop wine tourism activities but can even be further exploited especially if we consider the links between history, culture, art, tradition, craftsmanship, food and wine.

\section{Pairing Grands Crus of Burgundy}

According to Larousse Encyclopedia of Wine [55], there are 14 main wine families:

- light, tart, dry white wine;

- Supple, fruity dry white wine;

- Full-bodied, distinctive white wine;

- Very aromatic dry white wine;

- Medium sweet and sweet white wine;

- Lively, fruity rosé wine;

- Full-bodied vinous rosé wine;

- $\quad$ Light, fruity red wine;

- Full-bodied, fruity red wine;

- Complex, powerful red wine with a fine bouquet;

- Complex, tannic, distinctive red wine;

- Complex, elegant, distinctive red wine;

- Sparkling wine; 
- $\quad$ Vins doux naturels and fortified wine.

Only two clusters are appropriate for the Burgundy Grands Crus:

- Full-bodied, distinctive white wine (Chablis Grand Cru, Corton-Charlemagne, Montrachet.) Food matches with fairly sophisticated, flavorsome food: mushrooms, scallops, fried foie gras, cooked lobster, fish in a cream sauce, white meat in a cream sauce, creamy cheese such as Saint-Félicien, Saint-Marcellin, mature goat's cheese such as Picodon;

- Complex, elegant, distinctive red wine (Chambolle-Musigny, Vosne-Romanée, Gevrey-Chambertin, Corton, Pommard, Volnay). Food matches with flavorsome dishes simmered in a wine sauce: coq au vin, eggs en meurette, roasted white and red meat, small game birds or animals, fairly mild soft cheeses with a surface mould (Brie, Coulommiers).

Pairing wine and food is a matter in which there are neither absolute nor definitive rules. A gastronome's recommendations may be perceived as anathema by another. However, there are some basic rules which deserve to be mentioned even though they may be broken.

As an aperitif, wine is expected to awaken the taste buds and sharpen the senses. Light, lively wines such as a good aligoté, a dry white Burgundy or a crémant de Bourgogne, or even a light red wine serve the purpose but strong-bodied red wines, grands crus especially should be avoided.

Accompanying starters is crucial to the success of a meal because it is the time when diners have their first impressions. It is better not to offer wine with egg-based dishes, vegetable soup or dishes prepared with vinegar. On the other hand, cold cuts highlight wines: sausage with supple red wine, potted meat with stronger-bodied red wine or dry white wine. Great Chablis, Corton Charlemagne, Meursault or Montrachet or even an old red wine are a wonderful accompaniment for foie gras.

As for fish, tradition has it that they should be accompanied by a white wine. This rule still applies. With oysters, it is a good idea to serve light wines. For crustaceans such as crabs or prawns, a Bourgogne blanc or a village appellation white wine is quite relevant. Lobster requires a stronger-bodied, aromatic wine. Fish, whether served grilled, cooked in the oven, fried or poached will be accompanied by practically any dry white. A rule of thumb is "the more refined the fish, the better the quality of wine". Harmonizing fish in a sauce with wine is more of a challenge, the wine has to be stronger-bodied. If the fish is prepared with a red wine sauce, it should be accompanied by red wine.

Poultry offers a large range of possibilities. Red or white wines can be served as long as they are refined. A fairly light wine will accompany chicken or turkey, a stronger-bodied wine will accompany duck or goose. Crémant de Bourgogne may be served with chicken cooked in a sparkling wine sauce... Likewise, white and red wine can accompany game. However, with hare, wild boar, deer, a powerful red wine is recommended.

With red meat, red wine is almost a must, but why not improvise? Burgundy wines, because of their incredible variety, offer a lot of possibilities. However, it is advisable to refrain from serving beef or lamb with white wine. With white meat, including pork, supple red wines or aromatic whites may be served but tannic, strong-bodied reds would not be right. A factor which should also be considered is the sauce or the vegetables served with the main dish: they may deeply alter its savor.

Choosing the wines served with cheese is a very interesting challenge. Wine may enhance cheese but, too often, marvelous bottles are wasted because they accompany too strong cheeses. Contrary to an often accepted rule, cheese is best accompanied by white wine. Goat cheese, for instance, is enhanced by a dry white Burgundy. Red wines should be served with young, tender, soft cheeses. It is also advisable to keep older wines in the cellar.

Last but not least, contrary to a widespread opinion, Burgundy wines can be paired with some exotic dishes.

Crémant de Bourgogne is often served with desserts but the match is sometimes delicate.

After this general description on how to pair Burgundy wines, let us focus right now on the Grands Crus. In Table 4, there is a summary of the best food pairing with Burgundy Grands Crus. 
Each time, the Grand Cru is mentioned with the number of bottles produced and the approximate number of producers, which demonstrates the scarcity but also the diversity within the Grand Cru Appellations (each producer having his own style).

Table 4. Inventory of food pairing with Burgundy Grands Crus.

\begin{tabular}{|c|c|c|c|c|}
\hline$\#$ & Grand Cru & $\begin{array}{l}\text { Production } \\
\text { in Bottles }\end{array}$ & $\begin{array}{l}\text { Approximate } \\
\text { Number } \\
\text { of Producers }\end{array}$ & Best Food Pairing \\
\hline 1 & Chablis Grand Cru & 215,000 & 70 & $\begin{array}{l}\text { Offals such as calf's kidney; seafood: oysters, Dublin Bay } \\
\text { prawn fritters with mushrooms, summer Beaufort, } \\
\text { Salmon, trout, sturgeon, mackerel, tuna, bass, caviar, } \\
\text { quenelles of pike, snails à la Bourguignonne, fish soufflé, } \\
\text { ham and parsley in aspic jelly }\end{array}$ \\
\hline 3 & Ruchottes-Chambertin & 13,500 & 10 & $\begin{array}{l}\text { Mushrooms, breast of duckling, tenderloin pie, rabbit } \\
\text { with crystallized onions. }\end{array}$ \\
\hline 4 & $\begin{array}{l}\text { Chambertin-Clos } \\
\text { de Bèze }\end{array}$ & 55,000 & 20 & $\begin{array}{l}\text { Red meat in sauce with morels and truffles, game, hare, } \\
\text { partridge stew, Epoisses and Ami du Chambertin }\end{array}$ \\
\hline 6 & Griotte-Chambertin & 14,000 & 8 & Poultry from the Bresse, roasted beef \\
\hline 7 & Chambertin & 65,000 & 30 & $\begin{array}{l}\text { Beef cutlet with marrow, grilled slab of Charollais beef, } \\
\text { venison on the spit, cockerel in Chambertin, saddle of } \\
\text { hare, Epoisses and Ami du Chambertin, }\end{array}$ \\
\hline 8 & Latricières-Chambertin & 40,000 & 12 & $\begin{array}{l}\text { Game, mushroom dishes (chanterelles, morels, boletus } \\
\text { mushrooms,) mature but not too creamy cheeses }\end{array}$ \\
\hline 9 & Charmes-Chambertin & 150,000 & 70 & $\begin{array}{c}\text { Bœuf bourguignon, jugged hare, chevreuil terrine, } \\
\text { mature cheeses }\end{array}$ \\
\hline 10 & Mazoyères-Chambertin & 9000 & 3 & Grilled or roasted red meat \\
\hline 11 & Clos de la Roche & 75,000 & 30 & $\begin{array}{c}\text { Charollais beef, tournedos in red wine sauce, chicken } \\
\text { with morels, any dish with truffles, mature cheese } \\
\text { or Cîteaux }\end{array}$ \\
\hline 15 & Bonnes-Mares & 63,000 & 30 & $\begin{array}{l}\text { Meat in sauce, tournedos served with mushrooms, } \\
\text { feathered game, roasted wild boar }\end{array}$ \\
\hline 16 & Musigny & 35,000 & 12 & $\begin{array}{c}\text { Leg of lamb or roasted meat, stuffed turkey, veal with } \\
\text { morels, truffled Bresse poulard }\end{array}$ \\
\hline 17 & Clos de Vougeot & 215,000 & 85 & $\begin{array}{l}\text { Meat cooked with spices and mushrooms, game, cheese } \\
\text { (Reblochon, Cîteaux or Mont d'Or) }\end{array}$ \\
\hline 18 & Échezeaux & 160,000 & 60 & Fine meat, roasted feathered game, fruity cheeses \\
\hline 19 & Grands Échezeaux & 35,000 & 20 & $\begin{array}{c}\text { Poultry (guinea fowl or feathered game,) leg of roebuck, } \\
\text { gamy meat }\end{array}$ \\
\hline 20 & Richebourg & 35,000 & 12 & $\begin{array}{l}\text { Roasted game, wild boar, roebuck, slab of doe, hare, } \\
\text { Rossini tournedos, fruity cheese }\end{array}$ \\
\hline 21 & Romanée-Saint-Vivant & 36,000 & 10 & $\begin{array}{l}\text { Breast of veal stuffed with mushrooms, mushroom } \\
\text { dishes, truffles, morels, chanterelles, fruity cheese }\end{array}$ \\
\hline 22 & Romanée-Conti & 6000 & 1 & $\begin{array}{l}\text { Roast woodcock, truffled Bresse capon, Abbey of } \\
\text { Cîteaux cheese }\end{array}$ \\
\hline 23 & La Romanée & 4000 & 1 & $\begin{array}{c}\text { Most roast venison (roebuck, wild boar,) feathered game } \\
\text { in fine sauce }\end{array}$ \\
\hline
\end{tabular}


Table 4. Cont.

\begin{tabular}{|c|c|c|c|c|}
\hline \# & Grand Cru & $\begin{array}{l}\text { Production } \\
\text { in Bottles }\end{array}$ & $\begin{array}{c}\text { Approximate } \\
\text { Number } \\
\text { of Producers }\end{array}$ & Best Food Pairing \\
\hline 24 & La Grande Rue & 6500 & 1 & $\begin{array}{c}\text { White and red meats, game, and a wide array of fruity } \\
\text { and matured cheese }\end{array}$ \\
\hline 25 & La Tâche & 21,000 & 1 & $\begin{array}{l}\text { Game and meat in sauce, mushroom dishes } \\
\text { (truffles, morels) }\end{array}$ \\
\hline 26 & Corton & 480,000 & 150 & Meat in sauce, venison, quail, partridge, fruity cheese \\
\hline 27 & Corton-Charlemagne & 270,000 & 50 & $\begin{array}{l}\text { Lobster, spiny lobster, Venison cutlet, Bresse poulard in } \\
\text { cream, poulard with morels, calf's sweetbreads with } \\
\text { morels, truffled foie gras, orange duck, salmon with } \\
\text { sorrel or with a Dutch sauce, cheese (Beaufort, comté } \\
\text { or old Cantal) }\end{array}$ \\
\hline 28 & Le Charlemagne & 2000 & 1 & Idem Corton-Charlemagne \\
\hline 29 & Bâtard-Montrachet & 74,000 & 45 & $\begin{array}{l}\text { Pan-fried foie gras, lobster salad, fresh river crayfish, } \\
\text { truffled Bresse poultry }\end{array}$ \\
\hline 30 & Bienvenues-Bâtard-Montrachet & t $\quad 23,500$ & 12 & Lobster, truffle soup, turbot in cream \\
\hline 31 & Chevalier-Montrachet & 45,500 & 15 & $\begin{array}{c}\text { Lobster, fresh water crayfish, fish in a cream sauce or in } \\
\text { saffron, Bresse poultry stuffed with foie gras }\end{array}$ \\
\hline 32 & Montrachet & 31,500 & 20 & $\begin{array}{l}\text { Lobster, fres water crayfish tail, the finest fish, } \\
\text { salmon trout, pike }\end{array}$ \\
\hline 33 & Criots-Bâtard-Montrachet & 10,000 & 8 & Foie gras, fine fish, lobster soup, white meat \\
\hline
\end{tabular}

The best proposed food pairing is a general observation and ensures consistency among vintages, producers and even location within the grands crus, which is in practice far from being true. (1) Some vintages, especially those before 2000 can be very different: 1984 vs. 1985 or 1927 vs. 1928. Only the best vintages can have a long ageing capacity (to make their tannic structure softer and silkier) or alternatively, a rather weak vintage such as 2011 or 2013 can be paired now because of its lack of aging capacity (it will become watery at a certain point) and drinkability now. (2) Some producers of Echézeaux Grand Cru are above the average such as Domaine de la Romanée-Conti, Emmanuel Rouget or Méo-Camuzet, which is reflected in terms of price structure on the market. (3) Finally, the location within the Grand Cru parcel can influence quality a lot, especially in Grands Crus with large area: for example, in Clos-de-Vougeot, the bottom of Clos de Vougeot is not as good as the middle or the top of the Clos. When the monks were in charge of the vineyard management, it was said that the bottom of the Clos was for the local Church, the middle for the bishop and the top for the pope. Two centuries ago, the monks were already aware of differences in the quality of their wines.

Based on the courses listed in this table (next to each Grand Cru), we will review the dominant pairings for each Grand Cru and justify why the pairing works in consideration of the characteristics of these outstanding wines.

\subsection{The Grand Cru of Chablis and Its Plots}

According to Ginestet [56] Chablis wines are characterized by their fruity aromas (citrus, pear, apricot, passion fruit, bruised apple,) white flower aromas, minerality and salinity. One of their most appreciated traits is a long, tinglish finish of acidity and flint-like minerality.

The best food pairings take advantage of these wines' acidity to act as a palate cleanser. These wines should be accompanied by dishes with delicately creamy sauces, chicken tarragon, snails, clam chowder, truffle fricassee over creamy polenta, trout, bass, halibut ... 


\subsection{The Grands Crus of Gevrey-Chambertin}

The Grands Crus of Gevrey-Chambertin account for approximately 400,000 bottles produced by 150 owners. These wines have complexity and aromatic power that magnify over time. They will pair very well with fine, savory dishes without excessive seasoning such as roast red meat with truffles and morels. However, cheese is not recommended with most Grands Crus.

\subsubsection{Chambertin}

Bertin, a savvy farmer, owned a field next to the monks' estate. He felt that as his neighbors made good wine, he too would be a successful winegrower if he planted vines in his field. He was right. Bertin's field ("Le champ de Bertin") is a truly great wine. When young, it is austere but with ageing, it becomes rich and complex with floral aromas of rose and violet but also undergrowth, truffle, leather and chocolate and it pairs very well with dishes in sauce or gravy.

\subsubsection{Chambertin-Clos de Bèze}

Chambertin-Clos de Bèze is the oldest estate recorded in history. In 630, Amalgaire, Duke of Burgundy donated it to the Abbey of Bèze. This wine is powerful and complex with hints of red berries and some minerality. It will be great with dishes in sauce or with morels and truffles.

\subsubsection{Chapelle-Chambertin}

It is a fine wine with fruity aromas (especially, fruit with pits such as red cherries) but also liquorish. It opens up more rapidly. It pairs very well with any roasted or non-marinated meat.

\subsubsection{Charmes-Chambertin}

It needs time to express its aromatic subtlety. It has aromas of black currant, cherry, liquorish and violet. It accompanies refined or savory cuisine (especially with morels and truffles).

\subsubsection{Griotte-Chambertin}

In mouth, it has flavors of Morello cherry and the mouthfeel is silky and velvety. It pairs very well with simple meat but marinated game should be avoided because of its too marked savors.

\subsubsection{Latricières-Chambertin}

This wine has a powerful aromatic range with vegetal, mushroom, undergrowth, cherry and violet aromas. Mushroom dishes or rustic dishes will be a good accompaniment for this wine.

\subsubsection{Mazis-Chambertin}

It is a complex wine with aromas of black berries, cassis, cherry, liquorish, cocoa, mocha, caramel apple pudding, fur, humus, truffle, tobacco. The pairing is adequate with sophisticated or savory cuisine.

\subsubsection{Mazoyères-Chambertin}

The wine is well-balanced and subtle with spice and fresh tobacco aromas. Given its subtlety, it is preferable to avoid accompanying it with too spicy sauces and too mature cheeses.

\subsubsection{Ruchottes-Chambertin}

This wine has mineral character with black fruit and aromas of mushroom and truffle. It pairs very well with traditional or savory cuisine. 


\subsection{The Grands Crus of Morey-Saint-Denis}

Their structure is less marked than that of the Grands Crus of Gevrey-Chambertin. They open up more rapidly, have a fine structure and a rich fruity aromatic range. The total production is around 165,000 bottles vinified by approximately 40 different producers.

\subsubsection{Clos de la Roche}

This wine has aromas of ripe red and black fruit, wild cherry, huckleberry, rose and also aromas of spices, tobacco, humid wood, walnut and truffle. It accompanies well red or white meat, truffles or cheese.

\subsubsection{Clos des Lambrays}

This Grand Cru has fine aromas of red fruit (strawberry, raspberry, Morello cherry) and flowers (especially roses). With time, this wine acquires aromas of undergrowth, spices, liquorish, cooked apples and cocoa beans. It requires fine meat simply roasted in a fine sauce.

\subsubsection{Clos de Tart}

This wine has both power and finesse with a great aromatic complexity of red fruit and black berries, and also aromas of violet. The tannins merge with time and this wine reveals notes of sweet spices and undergrowth. It pairs very well with simple, savory roasted meat as well as dishes in sauce.

\subsubsection{Clos Saint-Denis}

It is a complex wine with notes of red fruit (strawberry) and fruit with pits (cherry and plum), spices, and cloves. In terms of pairing, it is better to avoid blue cheese and prefer savory cuisine (game and dishes in sauce) or cheeses which are not too creamy.

\subsection{The Grands Crus of Chambolle-Musigny}

The two Grands Crus are characterized by prevailing fresh red fruit (red currant, Morello cherry) and black fruit (blackberry), undergrowth and more floral notes for Musigny. White Musigny, however, is more "earthy" than white Vougeot (village or premier cru appellation) with notes of fresh mushrooms. Feathered game and dishes with mushroom will accompany these wines well.

\subsubsection{Bonnes-Mares}

The finesse and complexity of this Grand Cru will require sophisticated but not too spicy dishes. It should be noted that the section of Bonnes-Mares situated in Morey-Saint-Denis produces more tannic wines (Bonnes-Mares being located in the villages of Morey-Saint-Denis and Chambole-Musigny).

\subsubsection{Musigny}

Comte De Voguë who owns two-thirds of this Grand Cru, also owns a tiny plot of chardonnay in the Musigny climat. He produces 3000 bottles of white Musigny which ideally accompanies fine fish in sauce, poultry in cream with morels or ceps, squash soup ...

Red Musigny, which accounts for most of the production (32,000 bottles) is characterized by its subtlety. It reveals subtle notes of raspberry mixed with violet and liquorish. It has very good length. Therefore, it should be paired with simply roasted meat or leg of lamb.

\subsection{The Grand Cru of Vougeot: Clos de Vougeot}

The Clos, developed by Cistercians who owned it for over 650 years, produces wines with a good structure and aromatic intensity. After the French Revolution, it fell in the hands of Joseph Jules Ouvrard, who had made a fortune selling guns and military equipment for Napoleon's army. 
His family kept it until 1889. Afterwards, it was divided. As the area of the Clos is 51 hectares and as it is owned by 80 different owners, there are slight differences between the wines which are due to the location of plots and the winemaker's know how. When young, they reveal vegetal aromas, fruit aromas (raspberry, plum, cherry, blackcurrant, blackberry,) undergrowth and violet). With time, they reveal aromas of cooked fruits, mushroom, truffle and fur. These wines should be accompanied by sophisticated, savory dishes.

\subsection{The Grands Crus of Flagey-Echezeaux}

Those wines (with aromas of fruits, undergrowth, a hint of spices) are characterized by a lot of finesse and aromatic complexity.

\subsection{1. Échezeaux}

It is a complex wine with an aromatic spectrum ranging from red fruit to a background of floral notes. Dishes with light and fine sauces will pair very well with them. However, marinated meat and game would be too strong. Likewise, cheeses and spicy dishes should be avoided by all means. Instead, lamb or soft cheeses will be preferred.

\subsubsection{Grands Échezeaux}

This full-bodied and complex wine, which has aromas of raspberry, blackcurrant, a hint of pepper, grilled aromas, cocoa bean aromas, is full of finesse. It has a strong structure and should be served with savory, but not too spicy meats in sauce.

\subsection{The Grands Crus of Vosne-Romanée}

The Grands Crus of Vosne-Romanée are all different, ranging from firm Richebourg to fruity Romanée-Conti or delicate Romanée-Saint-Vivant. What they all have in common is the finesse of the fruit associated with earthy notes and a great aromatic complexity. As far as pairing them with food is concerned, too heavy, too fat or too spicy dishes should be avoided.

\subsubsection{La Grande Rue}

It has aromas of red fruit and spices with a touch of mint. Its structure is tight, its tannins are present so that this wine needs to age a few years before being served. Because of its fresh, fruity aromatic range and its structure, most red and white meats will accompany La Grande Rue. However, blue cheese should be avoided.

\subsubsection{La Romanée}

This wine should be kept a long time in the cellar. Years will enable it to become suppler and to release its aromas of black fruit and a hint of spices. Fine savory meats will be enhanced by this wine. However, spicy dishes, cream sauces and marinated dishes should be avoided.

\subsubsection{La Tâche}

This Grand Cru has a silky, velvety and smooth texture with notes of mushrooms and undergrowth. It has very complex aromas of red fruit. When ageing, it acquires aromas of undergrowth, mushrooms, dead leaves and humus. Therefore, game or meat in sauce but also mushroom dishes (truffles, morels) pair very well with it.

\subsubsection{Richebourg}

This wine has both a strong structure and finesse. It also has a complex range of aromas mixing earthy notes of mushrooms and ripe red berries or floral notes of peony and violet with sweet spices. 
Fine savory meats will accompany this wine. On the other hand, cream sauces and marinated meat dishes should be avoided.

\subsubsection{Romanée-Conti}

In Burgundy, a region priding itself for its sense of democracy, very few vineyards bear their owner's name. Romanée-Conti is the most famous exception. According to a legend which dies hard, Madame De Pompadour, the king's mistress, wanted to lay her hands on this estate. In 1760, Prince De Conti, the king's first cousin, purchased it from Philippe De Croonembourg who liked gambling too much and went bankrupt. Prince De Conti did not sell Romanée-Conti but generously offered it to his family and friends...

It is an intensely aromatic wine: an explosion of floral and red fruit aromas in its youth (violet, rose, cherry, raspberry and strawberry) while when older, the aromas turn into earl grey tea, withered rose, tobacco and cinnamon. Extremely fine and delicate dishes should be served with this wine characterized by its great finesse. Spicy dishes, marinades and cream sauces should be banned.

\subsubsection{Romanée-Saint-Vivant}

It has a nice and discreet structure. It is a very subtle wine with a complex aromatic range (mushrooms, red fruits, candied fruit, spices, wood and sometimes mineral). Romanée-Saint-Vivant should be served with roasted or smoked meat and more sophisticated, savory dishes.

\subsection{The Grands Crus of Aloxe-Corton, Pernand-Vergelesses and Ladoix-Serrigny}

\subsubsection{Corton}

Corton was Voltaire's favorite wine but the famous philosopher kept complaining that his wine did not travel well. In fact, dishonest wagoners dipped a hose in the barrels, sipped the wine and topped them with water. Only when a glass factory opened in Epinac, could the author of Candide, drink Corton bottles without added water.

About 480,000 bottles of red Corton are produced yearly but there is also a small production of white Corton estimated at around 25,000 bottles. This wine will go well with pike in mustard, foie gras, lobster, and fresh water crayfish ...

Red Cortons are considered by Doctor Lavalle [22] as the frankest and firmest wines of the Côte de Beaune. They have an intense color and aromas of red cherries and cassis evolving to undergrowth when they age, and they are powerful. They accompany duck, feathered game (thrush, pheasant, woodcock, and partridge), hare, roe, and young wild boar.

\subsubsection{Corton-Charlemagne and Le Charlemagne}

In 774, at the beginning of his reign, when Charles the Great was still king of the Francs, he donated his 2-hectare vineyard of Aloxe-Corton to the Abbey of Saint-Andoche, which had been destroyed by the Sarracens. The monks kept it for over 1000 years. The name Corton Charlemagne was given to the Southwestern part of the Corton hill. Although they are two different appellations (for legal reasons), their taste is rather similar. They are characterized by their minerality (flintstone) and vegetal aromas (fern, linden flower, juniper and pineapple). When older, cinnamon, fresh walnut, pepper, truffle, leather, amber, exotic fruits will be revealed. White Corton Charlemagne/Charlemagne are characterized by their strength, balance and grace. They accompany foie gras, lobster, pike, perch, char, and chicken with morels.

\subsection{The Grands Crus of Chassagne-Montrachet/Puligny-Montrachet}

The Montrachet hill ("Bald Mound") may be unassuming but Bienvenues-Bâtard-Montrachet, Bâtard-Montrachet, Chevalier-Montrachet, Criots-Bâtard-Montrachet (located on Chassagne-Montrachet side) and of course, Montrachet are exceptional wines. As of the 13th Century, the Cistercian Abbey of 
Maizières owned vineyards in Puligny and Chassagne. The names of the grands crus are explained in a story which is in fact a legend. After the death of his legitimate son (le chevalier, "the knight,") the landlord of Montrachet adopted his illegitimate son, le Bâtard, ("the Bastard") who was warmly welcomed by the winegrowers who said "Bienvenue! (Welcome) to him but the baby cried a lot (Criots). In 1787, when he visited Burgundy, Thomas Jefferson [1] ranked Montrachet as one of the greatest wines. He bought twelve cuttings that he planted in Monticello. Montrachet is the most precious and the most prestigious of all white Burgundies, as the price structure can reveal. It should be served with the finest dishes.

\subsubsection{Bâtard-Montrachet}

This Grand Cru has aromas of pear, raisin, cooked lemon, dried apricots, spices, grilled hazel nuts. It should be served with fresh water crayfish or poultry from the Bresse.

\subsubsection{Bienvenues-Bâtard-Montrachet}

This wine has aromas of white fruit, peach, citrus, a hint of mint, spices, cinnamon and honey. It can be paired with poultry from the Bresse in a cream sauce.

\subsubsection{Chevalier-Montrachet}

It has aromas of apple, orange, crystallized pineapple, almond and cinnamon. It is recommended to pair it with fresh water crayfish or vol-au-vent.

\subsubsection{Criots-Bâtard-Montrachet}

This wine has aromas of almond, ripe apples, white flowers, acacia, orange flower, salted butter, ginger bread, and hazel nuts. It can be paired with the finest fish, lobster, and poultry from the Bresse in cream.

\subsubsection{Montrachet}

This Grand Cru has a wide spectrum of aromas: white flowers, vanilla, hazel nuts, and honey. It is recommended to pair it with lobster, turbot in cream, or coulibiac (Russian dish consisting of salmon or sturgeon baked in pastry).

\section{Conclusions}

The quality of Burgundy wines has evolved over time. In the Middle-Ages, the Cistercian monks developed the notion of terroir which led to the creation AOC system in 1935. In the 1920s, especially thanks to Dijon Mayor Gaston Gérard's actions, the region became famous for its regional cuisine. The foire gastronomique and the ongoing development of automobile tourism contributed to the newly acquired fame of Burgundy. UNESCO's recognition of the vineyards of Côte de Beaune and Côte de Nuits as part of the world's heritage, is a major step towards people's awareness of the complexity of the region's vineyards. This recognition is expected to generate a further development of tourism and an increased interest in food and wine pairing. This is especially true of still affordable Grands Crus: in Burgundy, they cost more or less $25 \%$ of what consumers would pay for them in international cities.

For a long time, people in Burgundy paired wine with food in an empirical way. As long as the flavors of wine were not in conflict with the dominant flavors of dishes, they were satisfied. Indeed, wines went well with the local cuisine because they were both from the same region and everyone had always drunk them and eaten them together. Wine and food coexisted peacefully, sometimes unexcitedly. It was as if they had grown up together. In truth, it is hard to go wrong when matching the wines of a given region with the cuisine of that region. At a time when people drink far fewer but much better wines and pay attention to the quality of the food served in their plates, wine and food studies are developing. Knowledge plays a big part in the choice of the best value for money 
Grand Cru wines but also the best vintages and producers. Many resources such as wine guides, wine books, reedition of old books, wine magazines, blogs, etc., have been developed. Conversely, less knowledgeable consumers are not as likely to be wise purchasers. Thus, they need to rely more on the expertise of service providers working in shops and restaurants.

This review paper describes the villages where Grands Crus are located, the 33 grands Crus and the inventory of local food. Even if Burgundy is known both for its wines and its food products, they are rarely analyzed together, which makes this paper unique. The key contribution of this paper is to list all the best pairings of Burgundy Grands Crus and dishes. For each of the 33 Grands Crus, a review of the best-pairings is proposed from the angle of the specificities of each wine. It shows how and why unique Burgundy Grand Cru wines pair so well with foods, especially with the great variety and quality of the region's cuisine. What is more, Burgundy wines can also successfully open up to non-Burgundian food. Today, with globalization and the development of wine tourism, the challenge consists in finding the right food and wine matches in order to make them highlight each other's flavors. Ideally, the gastronomic sensations produced by wine and food harmoniously united should reach a perfection that they could not have reached independently from each other.

\section{Limits}

Some connoisseurs could claim that the Grands Crus of Burgundy are all great and therefore may be drunk regardless of the dish they accompany. It is of course true provided the food is delicate and not too spicy: in other words, unique Grands Crus should be paired with unique and fine courses. However, the 33 Grands Crus are not all of equal quality: in Chablis, the climat Les Clos is considered as the best one; in Aloxe-Corton, Corton-Charlemagne is sold at a higher price than Corton Grand Cru; in Flagey-Echézeaux, the quality of Grands-Echézeaux surpasses that of Echézeaux and this difference is therefore reflected in the price; in Gevrey-Chambertin, Chambertin and Chambertin-Clos de Bèze are by far considered topnotch etc. That is the reason why the price structure of each Grand Cru not only reflects its quality but also its scarcity.

Further research could also focus on the role of terroir in the matching of food and wine and how this role is translated into value for the consumer. It is a multi-disciplinary approach involving geology, the environment of the life cycle of the vines (especially sun exposure, drainage and location on the slope), viticulture (organic and biodynamic vs. conventional; and the clones planted in the plot), wine-making (the wine-maker's personal signature) and marketing (value perceived by the consumer).

Furthermore, the study could easily be extended to all Burgundy villages but it would increase the complexity and the length the paper: Burgundy has 100 appellations, 635 premier cru climats and there is a total of 1247 climats, just in the Côte de Nuits and the Côte de Beaune.

Some other villages such as Meursault, Volnay, Pommard or Nuits-Saint-Georges, which are currently without Grand Cru Appellation, could also be added to the study because they were highly regarded until the 1935 AOC law. Historically, some climats such as La Grande-Rue, which was upgraded in 1992, were not classified as Grand Cru. Likewise, Cros-Parentoux, a recent Premier Cru creation located in Vosne-Romanée was reclaimed by Henry Jayer. Clos Saint-Jacques in Gevrey-Chambertin is another good example. The rationale that was used in 1935 to establish the current list of Grands Crus was motivated by fiscal reasons, historical considerations, and political negotiations. However, consumers are not naive and the retail price reflects the quality of the wine even though the appellation is not what it deserves to be. Nowadays, there is a list of "super Premiers Crus": Clos Saint-Jacques in Gevrey-Chambertin, Cros Parentoux in Vosne-Romanée, Saint-Georges in Nuits-Saint-Georges, Rugiens in Pommard, Clos des Ducs or Clos du Château des Ducs in Volnay, or Goutte d'Or, Perrières, Genevrières or Charmes in Meursault. Conversely Corton grands crus such as Les Paulands or La Maréchaude which do not match Corton Le Clos du Roi or Corton Les Bressandes are sold at a lower price.

The producer is also a key factor of quality and his role deserves to be studied in another paper. Some regional appellations (Bourgogne or Bourgogne Aligoté) whose price is supposed to be around $€ 5$ are sold for more than $€ 100$, which is more than the price of some Grands Crus because the 
winemaker's expertise and fame is known worldwide. It is the case for instance for the Bourgogne Aligoté Sous Châtelet of Domaine d'Auvenay, the iconic estate run by the charismatic and energetic, Ms Lalou Bize-Leroy.

Last but not least, contrary to a widespread opinion, Burgundy wines can be paired with some exotic dishes. It would be interesting to further investigate in this direction. For instance, pairing Burgundy wines with Chinese cuisine: dry white Burgundies serve the purpose. On the other hand, the Chinese, accustomed to the tannins of tea, do not hesitate to accompany many dishes with red wine. Thus, Peking duck is highlighted by red Burgundies.

Conflicts of Interest: The authors declare no conflicts of interest.

\section{References}

1. Hailman, J.R. Thomas Jefferson on Wine; University Press of Mississipi: Jackson, MS, USA, 2006.

2. Young, A. Travels in France during the Years 1787, 1788 \& 1789; George Bell \& Sons: London, UK, 1909.

3. Michelet, J. History of France; Smith, G.H., Ed.; Appleton: New York, NY, USA, 1847.

4. Stendhal. Mémoires d'un Touriste; Slatkine: Paris, France, 1838; Reprints in 1986.

5. James, H. A Little Tour in France; Houghton, Mifflin Company: New York, NY, USA, 1884.

6. Proust, M. Sur la Lecture; Actes-Sud: Paris, France, 1907; Reprinted in 1988.

7. Laferté, G. La Bourgogne et Ses Vins. Images D'origine Contrôlée; Editions Belin: Paris, France, 2006.

8. Chapuis, C. L'Esprit du Vin; Timée: Boulogne-Billancourt, France, 2005.

9. Chapuis, L. Vigneron en Bourgogne; Éditions Robert Laffont: Paris, France, 1980.

10. Bazin, J.-F. Le vin de Bourgogne; Hachette: Paris, France, 1996.

11. Landrieu-Lussigny, M.-H.; Pitiot, S. The Climats and Lieux-Dits of the Great Vineyards of Burgundy: An Atlas and History of Place Names; Editions du Meurger: Vignoles, France, 2014.

12. Pitiot, S.; Servant, J.-C. The Wines of Burgundy; Collection Pierre Poupon: Beaune, France, 2010.

13. Weber, E. La Fin des Terroirs (Peasants into Frenchmen: The Modernization of Rural France, 1880-1914); Fayard: Paris, France, 1983.

14. Serres, M. La fin des Paysans. Le Monde (Daily), 21 December 2009.

15. Gérard, G. Dijon, ma Bonne Ville; Éditions des états-généraux de la gastronomie Française; Imprimerie Jobard: Dijon, France, 1959.

16. Fisher, M.-L. Long Ago in France: The Years in Dijon (Destinations); Prentice Hall Press: London, UK, 1991.

17. Cogan, L.; Charters, S.; Fountain, J.; Chapuis, C.; Lecat, B. Is good wine enough? Place, reputation and wine tourism in Burgundy. In Best Practices in Wine Tourism: Case Studies from Around the World; Thach, L., Charters, S., Eds.; Miranda Press: New York, NY, USA, 2016.

18. Chapuis, C.; Lecat, B. Embedding food and drink culture. In Food and Drink: The Cultural Context; Chapter 11; Sloan, D., Ed.; Goodfellow Publishers: Oxford, UK, 2013; pp. 114-133.

19. BOURGOGNES. Key Figures for the Bourgogne Wine Region. Available online: http://www.bourgognewines.com/press/gallery_files/site/289/38700.pdf (accessed on 23 July 2016).

20. BOURGOGNES Market Report. United States: Leading Export Market for Bourgogne Wines. Available online: http://www.bourgogne-wines.com/press/gallery_files/site/289/1910/35278.pdf (accessed on 23 July 2016).

21. Lucand, C. Les Négociants en Vins de Bourgogne: De la Fin du XIXe Siècle à nos Jours; Féret: Bordeaux, France, 2011.

22. Bazin, J.-F. L'émergence de la notion de climat en Bourgogne. Pays de Bourgogne: Les Climats, January 2012, No. 231, pp. 4-6.

23. Lavalle, J. Histoire et Statistique de la Vigne et des Grands Vins de la Côte d'Or; Phénix Editions: Ivry, France, 1855; 2000 ed.; the book is translated in English in: Curtis, C.; The Original Grand Crus of Burgundy; Wine Alpha: New York, NY, USA, 2014.

24. Fromont, C. La côte de Nuits au Grand Jour; Darantière: Dijon, France, 2013.

25. Fromont, C. La côte de Beaune au Grand Jour; Darantière: Dijon, France, 2005.

26. Poulain, C. Potage, Tortue, Buisson d'Écrevisses et Bombe Glacée ... . Histoire(s) de Menus; Agnès Viénot Editions: Paris, France, 2011.

27. Meffre, A.-C.; Covin, C. Escapades Gourmandes en Bourgogne; Editions Ereme: Paris, France, 2009. 
28. Carpentier, G. Cuisine Bourguignonne: 107 Recettes d'Hier et d'Aujourd'hui; Editions Ouest-France: Rennes, France, 2009.

29. Downie, D. Food-Wine-Burgundy; The Terroir Guides collection; The Little Bookroom: New York, NY, USA, 2010.

30. Morin, S. Les Recettes du Pays de Baubigny: 100 Recettes Bourguignonnes d'Hier et d'Aujourd'hui; Association les Fines Bouches: Baubigny, France, 2004.

31. De Grand-Maison, A. Le Guide des Vins et des Mets d'Accompagnement; Les éditions Québecor: Montreal, QC, Canada, 2000.

32. Guicheteau, G. Mets et Vins; Petits Pratiques Hachette: Paris, France, 1994.

33. Bourguignon, P. L'accord Parfait; Editions du Chêne: Paris, France, 1997.

34. Delpal, J.-L. Les mets et les Vins; Editions Artémis: Chamalières, France, 2007.

35. Simon, J. Wine with Food; Simon and Schuster: New York, NY, USA, 1996.

36. Harrington, R. Wine and Food Pairing - A Sensory Experience; John Wiley and Sons: Hoboken, NJ, USA, 2008.

37. Food and Wine the Westin Way; Brendan International Publications: Seattle, WA, USA, 1994.

38. Goldstein, E.; Goldstein, J.; Pool, J. Perfect Pairings; University of California Press: Oakland, CA, USA, 2006.

39. Courtépée, C. Description Générale et Particulière du Duché de Bourgogne; Delalain: Paris, France, 1775.

40. Broadbent, M. Pocket Vintage Wine Companion; Pavillion Books: London, UK, 2007.

41. Broadbent, M. Michael Broadbent's Vintage Wine: 50 Years of Tasting the World's Finest Wine; Little, Brown \& Company: Boston, MA, USA, 2002.

42. Senderens, A. Le Vin et la Table; Livre de Poche: Paris, France, 2000.

43. Bonin, S. L'Eiysée à Table. Un siècle de menus présidentiels. Magazine 3 Etoiles, 2005, p. 5.

44. Coates, C. The Wines of Burgundy; University of California Press: Berkeley, CA, USA, 2008.

45. Johnson, H. Hugh Johnson's Pocket Wine Book, 30th ed.; Mitchell Beazley: London, UK, 2006.

46. Meadows, A. The Pearl of the Côte: The Great Wines of Vosne-Romanée; Burghond Books: Winnetka, IL, USA, 2010.

47. Morris, J. Inside Burgundy: The Vineyards, the Wine \& the People; Berry Bros \& Rudd Press: London, UK, 2010.

48. Parker, R. Burgundy; Simon \& Schuster: New York, NY, USA, 1990.

49. Remington, N.; Taylor, C. The Great Domaines of Burgundy: A Guide to the Finest, 3rd ed.; Kyle Cathie Ltd.: London, UK, 2010.

50. Remington, N. Grand Cru: The Great Wines of Burgundy through the Perspective of Its Finest Vineyards; Kyle Cathie Ltd.: London, UK, 2010.

51. Hanson, A. Burgundy; Classic Wine Library, Mitchell Beazley: London, UK, 2003.

52. Kramer, M. Making Sense of Burgundy; Quill: MD, USA, 1993.

53. Ballantyne, D. Sustaining the promise of terroir: The case of the Central Otago Wine Region. In Proceedings of the 6th Academy of Wine Business Research Conference, Bordeaux, France, 9-11 June 2011.

54. Spielmann, N.; Charters, S. The dimensions of authenticity for terroir products. In Proceedings of the World Marketing Conference, Melbourne, Australia, 17-21 July 2013.

55. Larousse Encyclopedia of Wine; Hamlyn Edition: London, UK, 2001.

56. Ginestet, B. Chablis; Longman: London, UK, 1990.

(C) 2017 by the authors; licensee MDPI, Basel, Switzerland. This article is an open access article distributed under the terms and conditions of the Creative Commons Attribution (CC BY) license (http://creativecommons.org/licenses/by/4.0/). 